\title{
Incidence of and mortality from breast cancer among women in Poland in the years 2001-2010
}

\author{
Beata Leśniczak ${ }^{1}$, Grzegorz Krasomski ${ }^{1,2}$, Przemysław Oszukowski³, Tomasz Stetkiewicz ${ }^{4}$, Piotr Woźniak ${ }^{5}$ \\ ${ }^{1} 2^{\text {nd }}$ Department of Gynaecology and Obstetrics, Medical University of Lodz, Poland \\ 2Department of Obstetrics and Gynaecology, Polish Mother's Memorial Hospital - Research Institute, Lodz, Poland \\ ${ }^{3}$ Department of Perinatology and Gynaecology, Polish Mother's Memorial Hospital - Research Institute, Lodz, Poland \\ ${ }^{4}$ Department of Gynaecology and Gynaecologic Oncology, Polish Mother's Memorial Hospital - Research Institute, Lodz, Poland \\ ${ }_{5}^{5}$ Specialist Outpatient Clinics, Polish Mother's Memorial Hospital - Research Institute, Lodz, Poland
}

\begin{abstract}
Introduction: Breast cancer is the most common malignant tumour among women. About 15,000 new cases of breast cancer are diagnosed and more than 5,000 women die in Poland every year. The aim of this study was to analyse the incidence and mortality rate of breast cancer among women in Poland in the years 2001-2010.

Material and methods: Analysed data concerning the incidence of and mortality from cancer among women were obtained from the National Cancer Registry.

Results: The number of new cases reported in 2010 exceeded that reported in 2001 by 3,666. The mortality from breast cancer among women increased by $15.1 \%$ by 2009 , to subsequently drop by $0.3 \%$ in 2010 . The standardized incidence rate increased by 7.4 and the standardized mortality rate fell by 1.3 in 2001-2010.

Conclusions: In the years 2001-2010 the incidence of breast cancer in women in Poland rose by $30.3 \%$, with an increase of 7.4 in the incidence rate. The highest rise in the incidence and mortality of women due to breast cancer in Poland is reported in the Lodz voivodeship. In the years 2001-2009 the number of women's deaths due to breast cancer increased slightly, while the mortality rate dropped.
\end{abstract}

Key words: breast cancer, incidence, mortality, Poland.

\section{Introduction}

According to the World Health Organization report published in Copenhagen in 2003, cancers will be the principal cause of death in the $21^{\text {st }}$ century [1]. Breast cancer is the most common malignant tumour among women [2]. About 15,000 new cases of breast cancer are diagnosed and more than 5,000 women die of breast cancer in Poland every year [3]. According to the American National Cancer Institute, the risk of breast cancer during the woman's life is $12 \%$ and grows with age [2]. The highest incidence is reported in women aged 50-69 [3]. Estimated data indicate that the incidence of breast cancer will increase by about $35 \%$, while the number of deaths will remain relatively steady at about 14\% in Poland in 2025 [4].

The aim of this study was to analyse the incidence and mortality rates of breast cancer among women in Poland in the years 2001-2010.

\section{Material and methods}

Analysed data were obtained from the National Cancer Registry available on the website. The data con- cerned the incidence of and mortality from breast cancer among women in Poland in the years 2001-2010. Total numbers of new cases and deaths as well as standardized incidence and mortality rates by voivodeships were analysed in detail.

Standardized rates specify how many people would be affected by an illness or die of it per 100,000 of the population if the age structure of the population was the same as that in the population assumed to be the standard. The standard population was assumed to be "the standard population of the world" with data on its structure derived from the news bulletin "Cancer in Poland" edited by Joanna Didkowska, Urszula Wojciechowska and Witold Zatoński and issued by the Department of Epidemiology and Cancer Prevention Polish National Cancer Registry.

\section{Results}

The analysis of the collected material indicates that the incidence of breast cancer among women in Poland grew steadily. The number of new cases reported in 
2010 exceeded that observed in 2001 by 3,666, which means that the incidence of breast cancer among women increased by $30.3 \%$ over the analysed period. A particularly fast increase in the incidence - of 1,336, i.e. $12.2 \%$ - occurred in 2005 (Fig. 1).

In 2010 the standardized incidence rate exceeded that of 2001 by 7.4, even though it had decreased slightly in 2003, 2006, 2008 and 2010 (Fig. 2).

In 2001 the highest standardized incidence rates were reported in the West Pomeranian (55.1), Pomeranian (51.6) and Greater Poland (50.1) voivodeships, whereas the lowest rate was observed in the Lodz voivodeship (30.2). Ten years later the highest incidence rates were noted in the Pomeranian (59.1), Greater Poland (58.6) and Lodz (55.8) voivodeships, while the lowest rates occurred in the Świętokrzyskie (39.4) and Subcarpathian voivodeships (39.4) (Table I).

In the years 2001-2010 the highest rise in the incidence was reported in the Lodz voivodeship. The standardized incidence rate increased almost twofold and was higher than Poland's average which was 49.6. Simultaneously, incidence rates dropped in the West Pomeranian and Świętokrzyskie voivodeships, being 54.7 (55.1 in 2001) and 39.4 (42.5 in 2001) respectively.

The mortality from breast cancer among women increased by $15.1 \%$ by 2009 , to subsequently drop by $0.3 \%$ in 2010 (Fig. 1). Although the total number of deaths increased, the standardized mortality rate fell by 1.3 in the years 2001-2010 (Fig. 2).

In the analysed period the biggest changes in standardized mortality rates were noted in the Lubuskie, Masovian and Warmian-Masurian voivodeships and the smallest in the Greater Poland voivodeship. In 2001 the lowest standardized mortality rate was registered in the Lubuskie voivodeship (11.7) and the highest in the Greater Poland voivodeship (17.7) and Pomeranian

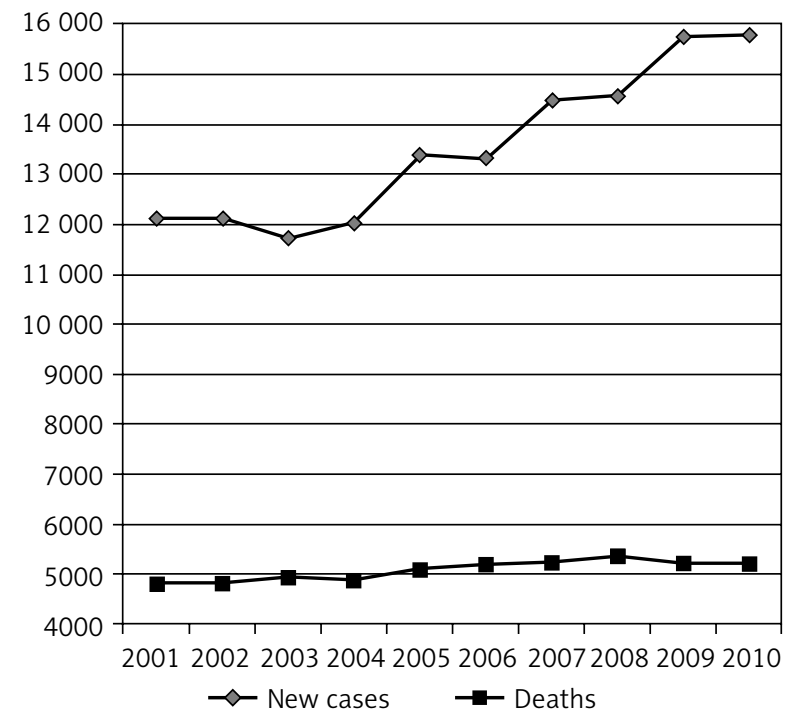

Fig. 1. Breast cancer among women in Poland in 2001-2010 number of new cases and number of deaths voivodeship (17.0). In 2010 the highest standardized mortality rates were reported in the Lodz (15.3), Silesian (15.3) and Kuyavian-Pomeranian voivodeships (14.8) and the lowest in the Podlaskie voivodeship (11.3) (Table II).

\section{Discussion}

The presented results of the analysis of changes in the breast cancer incidence and mortality of women point to the considerable importance of the discussed issue. As in other countries of the world, breast cancer is the most common malignant tumour in women and the most common cause of deaths due to malignant cancers in Poland $[2,5]$. The incidence has grown steadily for many years, by an average of about $3 \%$ a year. The incidence rate has increased, on average, by about 0.7 per year. A significant rise in the incidence has occurred in women over 50 years of age. It cannot be concluded, however, that breast cancer is a disease of menopausal age. Several cases of breast cancer are diagnosed in women up to 19 years of age every year. Women's mortality from breast cancer in absolute numbers is growing steadily as well, but the increase is not as fast as the rise in the incidence, and in 2010 the first slight drop in mortality was reported for the first time in many years. Simultaneously, the mortality rates have displayed a slightly downward trend since 2004. For comparison, 2,476 women developed breast cancer and 1,587 died of it in Poland in 1963. The incidence rate was 14.6 and the mortality rate was 10.0 . Twenty years later, there were 5,386 new cases and 3,664 women died. The incidence rose by $117.5 \%$ and the mortality increased by $131.9 \%$. Twenty years later the incidence rose again by $117.7 \%$ and the mortality increased by $34.9 \%$ [6].

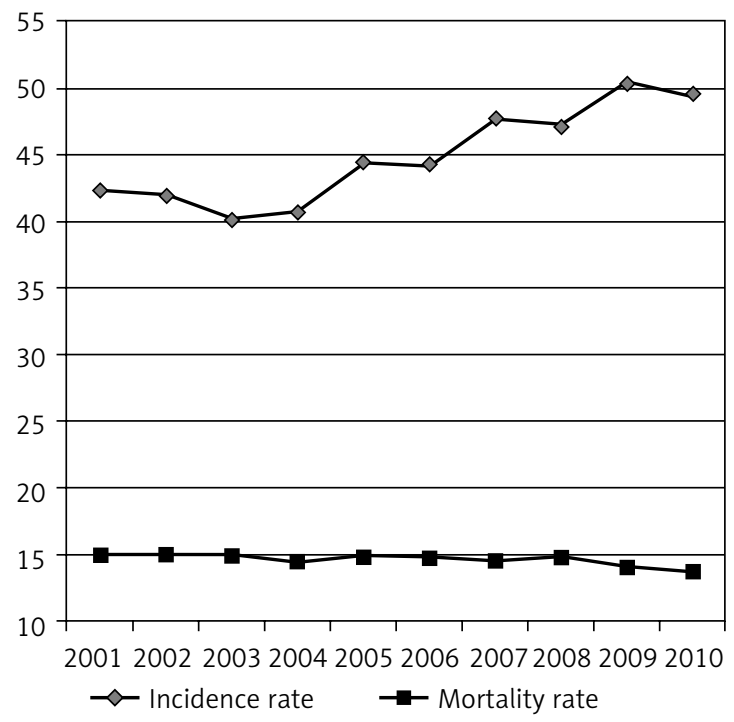

Fig. 2. Breast cancer among women in Poland in 2001-2010 - standardized incidence rate and standardized mortality rate 
Tab. I. Standardized incidence rate of breast cancer in women in Poland in 2001-2010 - by voivodeship

\begin{tabular}{lcccccccccc}
\hline Voivodeship & \multicolumn{1}{c}{ Year } \\
\cline { 2 - 10 } & 2001 & 2002 & 2003 & 2004 & 2005 & 2006 & 2007 & 2008 & 2009 & 2010 \\
\hline Lower Silesian & 48.1 & 46.8 & 41.4 & 47.2 & 47.3 & 50.5 & 56.2 & 52.3 & 52.6 & 52.7 \\
\hline Kuyavian-Pomeranian & 46.9 & 45.2 & 39.9 & 43.7 & 46.9 & 52.5 & 50.2 & 56.7 & 58.8 & 51.2 \\
\hline Lublin & 35.2 & 40.1 & 36.6 & 35.3 & 50.1 & 41.3 & 42.6 & 39.6 & 44.3 & 47.8 \\
\hline Lubusz & 39.3 & 30.1 & 32.8 & 29.4 & 43.2 & 45.8 & 54.9 & 47.2 & 51.4 & 51.1 \\
\hline Lodz & 30.2 & 36.5 & 33.2 & 43.0 & 49.8 & 48.0 & 48.8 & 51.9 & 54.6 & 55.8 \\
\hline Lesser Poland & 38.6 & 42.5 & 46.8 & 43.9 & 43.5 & 42.1 & 45.9 & 47.4 & 48.5 & 46.6 \\
\hline Masovian & 40.6 & 43.2 & 38.7 & 42.3 & 42.4 & 43.9 & 48.7 & 46.5 & 51.9 & 47.3 \\
\hline Opole & 40.3 & 39.4 & 34.5 & 38.8 & 39.5 & 42.1 & 46.5 & 45.6 & 47.6 & 42.0 \\
\hline Subcarpathian & 38.0 & 30.3 & 34.4 & 30.6 & 33.6 & 35.2 & 36.7 & 41.6 & 39.3 & 39.4 \\
\hline Podlaskie & 39.3 & 42.6 & 39.3 & 33.2 & 40.6 & 38.5 & 41.0 & 45.9 & 45.1 & 42.4 \\
\hline Pomeranian & 51.6 & 46.8 & 42.2 & 36.7 & 39.0 & 40.0 & 49.2 & 45.4 & 53.9 & 59.1 \\
\hline Silesian & 40.2 & 39.6 & 39.4 & 39.0 & 45.5 & 42.9 & 43.8 & 41.8 & 46.9 & 45.5 \\
\hline Świętokrzyskie & 42.5 & 42.6 & 39.2 & 35.1 & 37.6 & 39.0 & 40.5 & 39.5 & 44.3 & 39.4 \\
\hline Warmian-Masurian & 48.7 & 33.2 & 43.5 & 43.4 & 45.0 & 40.1 & 47.3 & 48.0 & 52.3 & 52.0 \\
\hline Greater Poland & 50.1 & 48.2 & 47.9 & 48.1 & 50.5 & 49.7 & 55.8 & 52.5 & 56.4 & 58.6 \\
\hline West Pomeranian & 55.1 & 54.2 & 46.6 & 39.3 & 45.8 & 45.2 & 48.7 & 49.7 & 50.3 & 54.7 \\
\hline Poland & 42.4 & 42.0 & 40.2 & 40.6 & 44.5 & 44.2 & 47.7 & 47.2 & 50.4 & 49.6 \\
\hline & & & & & & & & & \\
\hline
\end{tabular}

Tab. II. Standardized mortality rate of breast cancer in women in Poland in 2001-2010 - by voivodeship

\begin{tabular}{|c|c|c|c|c|c|c|c|c|c|c|}
\hline \multirow[t]{2}{*}{ Voivodeship } & \multicolumn{10}{|c|}{ Year } \\
\hline & 2001 & 2002 & 2003 & 2004 & 2005 & 2006 & 2007 & 2008 & 2009 & 2010 \\
\hline Lower Silesian & 13.3 & 14.6 & 14.9 & 14.5 & 13.3 & 14.0 & 14.7 & 15.1 & 13.1 & 12.3 \\
\hline Kuyavian-Pomeranian & 16.2 & 18.1 & 18.1 & 19.1 & 15.2 & 18.2 & 16.7 & 15.2 & 17.1 & 14.8 \\
\hline Lublin & 14.2 & 12.4 & 13.7 & 12.2 & 12.9 & 10.8 & 11.2 & 16.3 & 11.6 & 11.9 \\
\hline Lubusz & 11.7 & 12.3 & 15.0 & 13.6 & 15.7 & 17.9 & 12.8 & 13.7 & 12.0 & 14.2 \\
\hline Lodz & 14.7 & 13.0 & 15.6 & 14.5 & 15.0 & 15.3 & 14.6 & 14.4 & 14.9 & 15.3 \\
\hline Lesser Poland & 14.2 & 15.1 & 15.8 & 14.4 & 14.1 & 14.7 & 13.3 & 14.5 & 14.2 & 13.6 \\
\hline Masovian & 15.8 & 15.0 & 14.4 & 14.9 & 14.8 & 14.7 & 13.9 & 15.5 & 13.9 & 14.6 \\
\hline Opole & 14.4 & 14.5 & 15.7 & 12.5 & 11.7 & 10.9 & 12.2 & 15.8 & 12.0 & 12.1 \\
\hline Subcarpathian & 12.3 & 12.9 & 12.2 & 11.9 & 12.0 & 12.0 & 13.0 & 13.8 & 12.3 & 11.5 \\
\hline Podlaskie & 12.6 & 14.4 & 14.6 & 13.4 & 13.7 & 10.5 & 15.8 & 14.2 & 13.0 & 11.3 \\
\hline Pomeranian & 17.0 & 17.1 & 15.9 & 15.2 & 15.4 & 16.6 & 16.1 & 13.3 & 14.2 & 14.5 \\
\hline Silesian & 15.9 & 15.9 & 15.5 & 14.5 & 18.7 & 17.0 & 17.1 & 14.9 & 15.5 & 15.3 \\
\hline Świętokrzyskie & 14.3 & 14.0 & 15.8 & 11.8 & 13.3 & 12.9 & 13.9 & 16.4 & 13.7 & 13.6 \\
\hline Warmian-Masurian & 14.2 & 14.7 & 11.8 & 13.1 & 12.7 & 13.8 & 13.2 & 14.0 & 14.3 & 13.0 \\
\hline Greater Poland & 17.7 & 17.2 & 15.9 & 16.7 & 18.1 & 16.5 & 15.9 & 14.7 & 15.5 & 13.9 \\
\hline West Pomeranian & 14.4 & 14.3 & 13.8 & 15.0 & 12.2 & 14.1 & 13.5 & 14.0 & 13.1 & 11.7 \\
\hline Poland & 15.0 & 15.0 & 15.0 & 14.5 & 14.9 & 14.8 & 14.5 & 14.8 & 14.1 & 13.7 \\
\hline
\end{tabular}


The last decade's significant rise in the incidence of breast cancer among women in Poland is, to a large degree, connected with increased detectability after the implementation of a population-wide breast cancer early detection programme. The programme has been carried out in Poland by 16 Voivodeship Coordination Centres since 2007. Within the framework of the project, mammography examinations are performed in women aged 50-69 who have not had mammography done in the last 2 years and received a personal invitation to the test [7]. According to available data, mammography examinations were carried out in $39.8 \%$ of women in Poland in 2009. 77.3\% of women aged 50-59 and $73.9 \%$ of women aged $60-69$ underwent the test. Mammography examinations were most commonly done in women from the West Pomeranian, Opole and Pomeranian voivodeships, and the least commonly in female residents of the Świętokrzyskie, Lesser Poland and Warmian-Masurian voivodeships [8]. In the Lodz voivodeship, where the biggest rise in the incidence was reported in the analysed period, $21.81 \%$ of women, i.e. slightly over half the national average, underwent mammography examinations in 2009. The Lodz voivodeship ranks $12^{\text {th }}$ among the 16 analysed voivodeships in terms of women's attendance at mammography tests [7].

The risk of breast cancer increases with age. Breast cancer is a cancer whose first symptoms and signs occur after many years of latent growth. Preventive examinations often allow cancer to be detected as early as at its in situ stage, i.e. several years before the first symptoms and signs occur. They also significantly increase the incidence rate and reduce the age of women diagnosed with breast cancer. Early detection with the tumour size below $10 \mathrm{~mm}$ gives a chance to be successfully treated and increases the 5 -year survival rate, thus reducing women's mortality from breast cancer $[2,9]$.

In Poland, $50 \%$ of breast cancer cases are detected at an advanced stage, which considerably reduces the chances of successful treatment [9]. Along with mammography, methods enabling early detection of breast lesions include breast self-examination. The Polish Gynaecological Society recommends monthly self-examination to every woman from the age of 20 years [10]. According to the specialist literature, Polish women are not used to self-examining their breasts or undergoing prophylactic tests. About 20-25\% of women perform regular self-examination [11]. The study by Przysada et al. indicates that $41 \%$ of women are not aware of the need to have prophylactic examinations done and only $33 \%$ of women take advantage of screening tests [12]. According to Kozłowska et al., 1/3 of women do not know the symptoms of breast cancer and slightly more do not have knowledge of prophylactic examinations [12].

\section{Conclusions}

1. In the years 2001-2010 the incidence of breast cancer in women in Poland rose by $30.3 \%$, with an increase of 7.4 in the incidence rate.

2. The highest rise in the incidence and mortality of women due to breast cancer in Poland is reported in the Lodz voivodeship.

3. In the years 2001-2009 the number of women's deaths due to breast cancer increased slightly, while the mortality rate dropped.

\section{Disclosure}

Authors report no conflict of interest.

\section{References}

1. Florek-Łuszczki M. Poziom wiedzy mieszkanek wsi na temat czynników ryzyka zachorowania na nowotwór piersi oraz zasad profilaktyki. Medycyna Ogólna 2010; 16: 406-415.

2. Tkaczuk-Włach J, Sobstyl M, Jakiel G. Rak piersi - znaczenie profilaktyki pierwotnej i wtórnej. Prz Menopauzalny 2012; 11: 343-347.

3. Raports based on data of National Cancer Registry. epid.coi.waw.pl/krn/ (access May 2014)

4. Didkowska J, Wojciechowska U, Zatoński W. Prognozy zachorowalności i umieralności na nowotwory złośliwe w Polsce do 2025 roku. Centrum Onkologii, Warszawa 2009.

5. Wronkowski Z, Zwierko M, Nowacki M. Program modelowego skryningu raka piersi i raka szyjki macicy w Polsce, 1999-2000. Raport końcowy. Centrum Onkologii, Warszawa 2011.

6. Wojcierowska A, Renn-Żurek A, Dziedziczak-Buczyńska M, et al. Programy profilaktyczne dla kobiet realizowane na terenie województwa tódzkiego. Problemy Higieny i Epidemiologii 2010; 91: 511-516.

7. Stan zdrowia ludności Polski. GUS, Warszawa 2011.

8. Najdyhor E. Krajewska-Kułak E, Krajewska-Ferishah K. Wiedza kobiet i mężczyzn na temat profilaktyki raka piersi. Ginekol Pol 2013; 84: 116125.

9. Rekomendacje Zarządu Głównego PTG w sprawie profilaktyki i wczesnej diagnostyki zmian w gruczole sutkowym. Ginekologia Praktyczna 2008; 87: 14-15

10. Nita R, Leśniczak B, Słomska B, et al. Wiedza i zachowania zdrowotne kobiet z województwa tódzkiego w zakresie profilaktyki raka piersi. Pielęgniarstwo XXI Wieku 2010; 1-2: 5-8.

11. Przysada G, Bojczuk T, Kuźniar A. Poziom wiedzy kobiet na temat profilaktyki i wczesnego rozpoznawania raka piersi. Young Sports Science 2009; 3: 129-136.

12. Kozłowska E, Szewczyk M, Banaszkiewicz Z, et al. Knowledge of symptoms and diagnostics possibilities of cancer diseases. Arch Med Sci 2011; 7: 304-309. 